Summer 2005

\title{
Comment: Autonomy and the Public-Private Distinction in Bioethics and Law
}

Susan H. Williams

Indiana University Maurer School of Law, shwillia@indiana.edu

Follow this and additional works at: https://www.repository.law.indiana.edu/ijgls

Part of the International Law Commons, Legal Ethics and Professional Responsibility Commons, Legislation Commons, and the Science and Technology Law Commons

\section{Recommended Citation}

Williams, Susan H. (2005) "Comment: Autonomy and the Public-Private Distinction in Bioethics and Law," Indiana Journal of Global Legal Studies: Vol. 12 : Iss. 2 , Article 7.

Available at: https://www.repository.law.indiana.edu/ijgls/vol12/iss2/7

This Symposium is brought to you for free and open access by the Law School Journals at Digital Repository @ Maurer Law. It has been accepted for inclusion in Indiana Journal of Global Legal Studies by an authorized editor of Digital Repository @ Maurer Law. For more information, please contact rvaughan@indiana.edu.

\section{$\Psi$}

JEROME HALL LAW LIBRARY

INDIANA UNIVERSITY

Maurer School of Law
Bloomington 


\title{
Comment: Autonomy and the Public-Private Distinction in Bioethics and Law
}

\author{
Susan H. Williams*
}

In American law school classrooms, we have a phenomenon that I expect you experience here in Italy as well. The professor asks a question and the student attempts to avoid answering the question by challenging or seeking to shift the underlying assumptions the teacher has so carefully crafted to frame the issue. We call this "fighting the hypothetical," and I am afraid that that is what I am about to do.

The current debates in biolaw, in Cinzia's elegant description of them, ${ }^{1}$ rest on a particular assumption that I would like to highlight and examine. The assumption is that there is a fundamental difference between private and public systems of ordering and that this difference is, and should be, the salient feature in organizing our thinking about the intervention of law in this social arena. This assumption is, of course, a basic part of the liberal legal tradition, but it is an assumption that has been challenged from a variety of perspectives, including Marxist, communitarian, and feminist approaches. I will focus on the feminist criticism. While I find the critique persuasive, and I hope you will as well, I do not mean to suggest that an appropriate analysis would simply ignore the differences between exercises of power, some of which promote autonomy and some of which frustrate it. The lesson we should take from the critique is not that power, whether public or private, is an undifferentiated whole, but rather that we must be more precise in defining what are the relevant moral differences between exercises of power. Our approach must be more sensitive to the presence or absence of these moral qualities regardless of the nominally public or private identity of the persons who wield that power.

*Walter W. Foskett Professor of Law, Indiana University School of Law-Bloomington. This comment was delivered at a symposium on Back to Government? The Pluralistic Deficit in the Decisionmaking Processes and Before the Courts, June 2004, in response to Cinzia Piciocchi, Bioethics and Law: Between Values and Rules, 12 IND. J. Global Legal Stud. 47 I (2005).

1. See Cinzia Piciocchi, Bioethics and Law: Between Values and Rules, 12 Ind. J. Global Legat STUd. 471, 475-76 (2005) (paper presented at Symposium, Back to Government? The Pluralistic Deficit in the Decisionmaking Processes and Before the Courts, Trento, Italy (June 2004)). 
In this comment, I will offer some preliminary thoughts about this project of reconceiving the significance of public and private. First, I will trace the importance of this distinction in the clear and concise description of biolaw in Cinzia's paper. Then I will outline the feminist critique, with particular attention to its applications in bioethical/legal issues. Finally, I will suggest that the concerns about individual autonomy that underlie the traditional public-private distinction, while legitimate, are better served by directing our attention to the ways in which power facilitates or frustrates autonomy. In particular, the focus of this analysis should be on the effects of power on a more relational and less individualistic model of autonomy, rather than on the public or private nature of the person or institution who wields that power. There are important, morally significant issues in the exercise and structure of power, and they do indeed concern individual autonomy, but the focus on the public or private nature of power and the adherence to an individualistic model of autonomy obscure rather than illuminate these issues.

Cinzia offers a view of the current landscape of biolaw in which individual choice has become the central moral reality, replacing the biological facts on which the law used to rely. ${ }^{2}$ In response to these changes, Cinzia identifies three major approaches advocated by scholars of biolaw. The first approach sees the role of law as minor and argues that the ethical issues posed by these new technologies should be left to the "private-individual sphere," to be resolved by "individual conscience and self-regulation" within private institutions, such as hospitals and medical professions. ${ }^{3}$ The second approach adopts the other extreme view, arguing that law should regulate these ethical choices fully, imposing a particular moral vision and ensuring that private individuals and institutions comply with it. The ethical choices here are made by public institutions through the mechanisms of politics and law rather than by private parties. ${ }^{4}$ The third approach takes an intermediate approach, suggesting a role for law in protecting certain basic rights and imposing procedures designed to maximize autonomy rather than to impose a particular moral vision. Thus, the public institutions set a minimum ethical threshold and then support private individuals in making the ethical choices that remain to them above that threshold. ${ }^{5}$

2. See id. at $471-75$.

3. Id. at 476 .

4. Id.

5. Id. 
Cinzia suggests that the third, intermediate approach is the preferable one, and I do not disagree with her on that point. But, I think it is noteworthy that all three approaches, while offering very different solutions, frame the problem in the same way. They all see the central issue as concerning who shall make the ethical choices, and they all see the primary contenders as public bodies on the one side and private individuals and institutions on the other. To allocate control to public bodies is understood as authorizing the imposition of a particular substantive moral vision through regulation that will restrict individual choices. To allocate control to private persons and institutions is understood as freeing those private entities to follow their own moral visions. Both of these paths have certain advantages and certain dangers, which Cinzia ably outlines, and each of the approaches she describes balances those in different ways. ${ }^{6}$ They disagree about which risks are most important and about the relative weights that should be accorded to social morality and to individual autonomy. All three approaches agree, however, that the central meaning of public power here is the coercion of private individuals in accordance with a socially imposed moral vision and that the central meaning of private power is the freedom of individuals to follow their own moral visions.

This agreement is unsurprising given the fundamental reliance of the liberal legal tradition on some form of public-private distinction. The public-private distinction has, of course, been the subject of extensive criticism in feminist theory. ${ }^{7}$ I will outline several of the criticisms and illustrate them with examples from the law regarding biomedical issues. These criticisms demonstrate that the publicprivate distinction obscures rather than illuminates the crucial issues concerning individual autonomy. Private ordering cannot simply be equated with freedom, nor can public ordering simply be equated with social coercion. The effects of power on autonomy are more complex than this assumption suggests and require attention to the details rather than simply to the source of the power.

The first criticism of the public-private distinction as marking the boundary between freedom and coercion points out that private power can be just as coercive as public power in the lives of many people. This point is rather obvious in the

6. Id. at $476-78$.

7. For a sampling of such criticism, see generally Feminism, the Public and the Private (Joan B. Landes ed., 1998); Challenging the Public/Private Divide: Feminism, Law, and Public Policy (Susan B. Boyd ed., 1997); Carol Pateman, Feminist Critiques of the Public/Private Dichotomy, in Public and Private in Social Life 281 (Stanley I. Benn \& Gerald Gaus eds., 1983). 
economic realm, where private economic actors exert enormous power over individuals, but it is equally true in the realms of the family and the health care facility, where medical decisions take place. Feminist theorists have pointed out that private power exercised in the family-in the forms of physical abuse, economic power, or even social and psychological power-is a major cause of women's subordination in public realms. ${ }^{8}$ Even when women enjoy equal legal status, they do not enjoy actual equality if they are subject to abuse at the hands of private persons.

In the medical context, such private power can be exercised either by family members or by health care professionals. For example, a husband might pressure a wife not to have an abortion. The absence of a state law forbidding the abortion does not free the woman to make the choice because the exercise of private power by her husband is just as effective a barrier as the exercise of public power might be. The exercise of private power here is so clear an intrusion on the autonomy of the woman that the U.S. Supreme Court has held that it is a violation of the U.S. Constitution for a state to require a woman to notify her husband that she is seeking an abortion. ${ }^{9}$

Another example of private power's interfering with autonomy-this time involving medical professionals-is the practice of directive counseling. Many health care professionals in the United States believe that it is their right and their duty to counsel women with HIV to abort a pregnancy..$^{10}$ There are reasons why the choice to continue such a pregnancy might be a reasonable one for some women. But the important point is not whether a woman would be right or wrong in making such a choice, but that the private power of doctors would be used to prevent her from doing so. Again, a choice that is allocated to her by law may in fact be coerced through the exercise of private power.

One might object to this argument by pointing out that the autonomy guaranteed by law is, and should be, only negative liberty rather than positive liberty." There are many kinds of barriers and incapacities that might prevent

8. See, e.g., Susan B. Boyd, Challenging the Public/Private Divide: An Overview, in Challenging the Public/Private Divide: Feminism, Law, and Public Policy, supra note 7, at 10.

9. See Planned Parenthood v. Casey, 505 U.S. 833, 893 (1992).

10. See Ronald Bayer, AIDS and the Future of Reproductive Freedom, 68 Milbank Q. 179, 193 (1990).

11. For discussions of negative and positive rights, see David P. Currie, Positive and Negative Constitutional Rights, 53 U. CHI. L. Rev. 864 (1986); Ran Hirschl, "Negative" Rights v. "Positive" Entitlements: A Comparative Study of Judicial Interpretations of Rights in an Emerging Neo-Liberal Economic Order, 22 Нuм. RTs. Q. 1060, 1063 (2000). 
people from exercising rights the state has given them. It is not the obligation of the government to remove all such hindrances but simply to get out of the way itself. There are two responses to this counterargument and they form the next stages of the critique of the public-private distinction.

First, vulnerability to such exercises of private power is neither equally nor arbitrarily distributed; rather it follows clearly established hierarchies of gender, race, and class. ${ }^{12}$ In other words, not everyone experiences vulnerability to private power to the same extent. Women, for example, are much more likely to be the victims of domestic violence than men. And, in the example of directive abortion counseling, which I mentioned earlier, women who are poor or of minority races are more likely to be subjected to such practices in the United States. ${ }^{13}$ Thus, the vacuum created by the absence of public regulation is not a neutral limitation on everyone; it will reliably reinforce existing social hierarchies.

Second, these exercises of private power are facilitated by the original organization of resources imposed and maintained by the state. ${ }^{14}$ As a result, the state has some responsibility for such exercises of private power. For example, the state licenses medical professionals and authorizes them to maintain a monopoly over the provision of certain health services. It thereby creates and maintains the very power they exercise when they coerce their patients into a particular course of medical treatment. More subtly, but no less powerfully, the state also imposes the collection of laws that support the power of men over women in the family, including (in the United States, for example) tax laws that penalize families with two incomes, the failure to support adequate child care facilities, and employment regimes that penalize workers with child care responsibilities. Thus, state facilitation and coercion lie behind many exercises of private power.

Finally, one cannot equate public power with coercion and private power with freedom because the exercise of power by the state can sometimes support private autonomy rather than interfere with it. Thus, in the abortion context, the U.S. Supreme Court has approved the use of a judicial bypass procedure that allows a minor seeking an abortion to avoid notifying her parents if she can con-

12. See Nicola Lacey, Theory into Practice? Pornography and the Public/Private Dichotomy, 20 J.L. Soc'y 97 (1993).

13. See Taunya L. Banks, Women and AIDS_Racism, Sexism, and Classism, 17 N.Y.U. Rev. L. \& Soc. Change 351, 379 (1989-90).

14. Cf. Stephen Holmes \& Cass Sunstein, The Cost of Rights: Why Liberty Depends on TAxes (1999) (describing how the exercise of private, negative rights is dependent on public support). 
vince a judge either that the abortion is in her best interest, or that she is mature enough to make the decision by herself. ${ }^{15}$ The intervention of a public decisionmaker facilitates the autonomy of a minor who might otherwise be subject to the overriding private power of her parents. Similarly, a requirement that hospitals provide a staff person to offer nondirective counseling or to act as a patient advocate can help to reduce the influence of a doctor who is seeking to coerce the patient's choice.

The middle path in biolaw that Cinzia describes, recognizes that public regulation can have this autonomy-enhancing effect in the form of procedures that support autonomy. For this reason, her middle path is an improvement over the other two, more extreme views, which see government action only as imposing a moral vision on individuals. But I disagree with describing such regulations in procedural terms. In some cases, the regulations are best understood as substantive because they serve to shift power away from some private parties and toward others. For example, holding that spousal notification provisions are unconstitutional in the abortion context is not simply a procedural rule; it represents a substantive judgment that it is unacceptable to compromise the woman's autonomy, even in the interest of the father's participation in this important decision. The distinguishing characteristic of such rules is not that they are procedural rather than substantive. It is, instead, that an important part of the substantive ethical vision they promote involves the support and facilitation of individual autonomy. By characterizing such rules as procedural, the middle path perpetuates the liberal association of public and private with coercion and freedom.

For all of these reasons, then, the public-private distinction, as traditionally used, does not mark the boundary between collective coercion and individual autonomy. If we are truly concerned about the issue of autonomy, then we need to focus not on the public or private nature of the source of the power or regulation but on whether the distribution of power at issue promotes the value of autonomy or whether it frustrates autonomy in the interest of other values. Moreover, the feminist critique makes it plain that there is no position for the state here that avoids the imposition of a moral vision. Even anarchy is a choice about the values to be imposed, where those values place a particular model of individual autonomy above all other concerns. Thus, I would recast the issue in

15. See Hodgson v. Minnesota, 497 U.S. 417, 457 (1990). 
the following way: the question is not whether to impose a particular moral vision-that is inevitable-but rather what role individual autonomy should have within that vision, as compared to other values. And we cannot begin to approach that issue sensibly until we recognize that autonomy cannot be assumed in private ordering, nor is it necessarily frustrated by public ordering.

The second way in which I wish to "fight the hypothetical" concerns the model of autonomy we should use in answering these difficult questions. The traditional model of autonomy in liberal legal thought, with its foundations in the work of Kant, Locke, and Mill, is fundamentally individualistic. It sees the central moral activity as choice and it sees the autonomous agent as one who chooses through a process of rational reflection on his values and desires rather than being coerced (or perhaps even influenced) by forces outside himself. ${ }^{16}$

There is a particular conception of the person implicit in these liberal models of autonomy. First, the person is seen primarily as an agent: a doer and a chooser. It is this role that confers the moral status of personhood-that makes one, in Kant's terms, an end in itself. ${ }^{17}$ Second, the person is essentially self-transparent; that is, people are effectively able to look into themselves and see what their motives and values are in order to reflect and act upon them. We may sometimes struggle to overcome desires in ourselves that we do not like, but recognizing and identifying our desires is, in normal cases, a fundamentally straightforward process in which no other person could possibly be in a better position to know one's mind than oneself. Third, the person is essentially unified. We may sometimes have conflicting desires, of course, but we must possess essentially unified systems of values and desires if we are ever to rely on such systems to generate our choices. Indeed, the process of autonomous reflection can be understood as a form of internal housekeeping, in which we bring an increasingly greater degree of order and coherence to our motivational structure. And, finally, the person is essentially individualistic. Many modern autonomy theorists do recognize the contribution made by social relationships to the formation of autonomy: they acknowledge that we learn to be rational through social inter-

16. See Marilyn Friedman, Self-Rule in a Social Context: Autonomy from a Feminist Perspective, in Freedom, Equality, and Social Change 158, 159 (Creighton Peden \& James P. Sterba eds., 1989). For a full description of the liberal model of autonomy, the feminist criticisms of it, and a particular version of a relational alternative, see generally Susan H. Williams, Truth, Autonomy, and Speech: Feminist Theory and the First Amendment (2004).

17. See Immanuel Kant, Foundations of the Metaphysics of Morals and What is EnlightENMENT? 48-49 (Lewis White Beck trans., 1959). 
action. ${ }^{18}$ But such theorists generally see the exercise of autonomy itself as a fundamentally individual activity. That is, once a person has been trained through her social relations to reflect rationally, she could, in theory, go on being autonomous alone on a desert island. Indeed, if she could have been trained to be rational by a computer, she could have been autonomous without ever knowing another human being because the capacities required for autonomous actionwill, reason, and so on-are all understood as comprehensible without reference to social relationships. ${ }^{19}$

Now let me sketch an alternate, relational model of autonomy. In this model, the person is fundamentally embedded in social relations. This shift has important implications for the characteristics of the self and the meaning and function of autonomy. First, people are not necessarily unified. Because their identities are permeated by their relation to a complex and contradictory social world, people may find themselves with overlapping and even contradictory identities. Diana Meyers has called such identities "intersectional," and has pointed out that they are a resource for autonomy: because people belong to multiple groups, they can use the experience of distance from any one of them to gain critical insight and open possibilities for new interpretations. ${ }^{20}$

Relational models also reject the transparency of the liberal self. Once the social sources of our identities are recognized, it becomes apparent that someone else who shares my culture might be able to understand me better than I understand myself. ${ }^{21}$ Indeed, self-knowledge, in a relational model, is a difficult and important achievement, and self-ignorance is one of the greatest obstacles to autonomy. The process of coming to know ourselves, moreover, is a fundamentally social one: we need other people in order to engage in this process of selfknowledge, and they participate as potential sources of knowledge about us, rather than simply as sounding boards. ${ }^{22}$

18. See, e.g., Robert Young, Personal Autonomy: Beyond Negative and Positive Liberty 41 (1986).

19. See, e.g., Alfred R. Mele, Autonomous Agents: From Self-Control to Autonomy 22829 (1995).

20. See Diana Tietjens Meyers, Intersectional Identity and the Authentic Self? Opposites Attract!, in Relational Autonomy: Feminist Perspectives on Autonomy, Agency, and the Social Self 163 (Catriona Mackenzie \& Natalie Stoljar eds., 2000) [hereinafter Relational Autonomy].

21. See id. at 157.

22. See Catriona Mackenzie, Imagining Oneself Otherwise, in Relational Autonomy, supra note 20 , at 140 . 
And, of course, a relational model rejects the individualism of the liberal model. When we see ourselves as embedded rather than separated, we become aware that autonomy requires a whole range of capacities, many of which are explicitly tied to social relationships. The capacities explored by relational autonomy theorists include imagination, memory, communication, self-respect, and the ability to connect to other people. ${ }^{23}$ These capacities are relational in their genesis: we acquire such capacities through relationships with other people (e.g., parents, teachers, and friends). ${ }^{24}$ They are relational in their substance: the very content of such capacities is set by our social circumstances (i.e., what we can imagine is dependent on our cultural resources). ${ }^{25} \mathrm{But}$, most fundamentally, many of these capacities are inherently relational: they are not even comprehensible outside of a social setting (for example, communication or ability to connect to others). If the exercise of these capacities is necessary to autonomy, then it is not even theoretically possible that a person could be autonomous without ever having contact with other persons.

A relational model of autonomy shifts our focus from the internal deliberations of an individual to the network of relationships and institutions that provide the context for that deliberation. In particular, a relational model highlights the ways in which resources and opportunities for autonomy are not equally distributed in our societies. ${ }^{26}$ Negative social images of particular groups, say women or racial minorities, can affect the ability of members of such groups to be autonomous by interfering with the social relations on which autonomy depends. For example, there is a large literature documenting the denials of credibility to women, not only when they are claiming sexual abuse by men, but also more generally. ${ }^{27}$ If autonomy is dependent upon relationships in which one can explore one's identity with others, then the habitual refusal of others to listen or to believe is a serious interference with autonomy. ${ }^{28}$

23. See Meyers, supra note 20, at 166.

24. See Annette Baier, Postures of the Mind: Essays on Mind and Morals 83-90 (1985).

25. See Mackenzie, supra note 22, at 142-44.

26. Cf. Margaret Urban Walker, Moral Understandings: A Feminist Study in Ethics 10607 (1998).

27. See Kathy Mack, Continuing Barriers to Womens' Credibility: A Feminist Perspective on the Proof Process, 4 Crim. L.F. 327,328 n.3 (1993).

28. Or even with identity itself. See Susan J. Brison, Outliving Oneself: Trauma, Memory, and Personal Identity, in Feminists Rethink the Self 29 (Diana Tietjens Meyers ed., 1997). 
I would like to suggest that a relational model of autonomy better explains the ways in which public and private power interact either to facilitate or to frustrate individual autonomy and, therefore, this model is a more promising basis for legal analysis. A relational model is better because it does not assume that simply being left alone is all that is required to allow for autonomy. It focuses on the social conditions and relations that are necessary rather than only on the internal process of reflection. The relational model sees public power as both a potential threat to autonomy and a potential ally for autonomy because public power can be exercised in ways that disrupt the relations and capacities on which autonomy depends or in ways that support those relations and capacities. Private power, similarly, can be either positive or negative from the perspective of relational autonomy. A relational model demands a more detailed and nuanced approach, one that asks about the experience of the people involved, and how these structures affected them rather than reducing the issue to who has the ultimate power over the decision.

Let me end with an illustration. Courts and legislatures have been struggling for some time now with how to respond to reproductive technologies in which a woman sells her gestational capacity to a couple who wishes to have a child but otherwise cannot. The traditional version of this involved what is sometimes inaccurately called surrogate motherhood in which the woman who is both the genetic and gestational mother of a child conceived through artificial insemination agrees to relinquish the child at birth to the man who was the sperm donor and his wife. ${ }^{29}$ The more recent version involves the in vitro fertilization of an egg and sperm taken from a married couple and the implantation of the pre-embryo in a different woman who will gestate the fetus and relinquish it at birth to the genetic parents. ${ }^{30}$ From the perspective of the three approaches outlined by Cinzia, the issue here would be whether to leave the control of such technologies to the private regulation of doctors and clinics and the private choices of the individual parents involved, or whether the state should decide when such arrangements are acceptable, if ever, and pass legislation controlling these practices. The issue is complicated by the many related issues that arise in these transactions, such as: what to do with fertilized ova that are not actually implanted, what to do when one or more of the participants

29. This is the famous "Baby M" case. See In re Baby M, 537 A.2d 1227 (N.J. 1988).

30. See, e.g., Johnson v. Calvert, 851 P.2d 776 (Cal. 1993). 
changes his or her mind after the pregnancy begins, what to do if the child is born with a disease or disability, and so on.

A relational model of autonomy does not mandate a particular solution to these difficult problems, but it directs our attention to some aspects of the situation that are obscured by the focus on state regulation versus private choice. First, the relational model asks how the participants in these transactions understand their own roles and why they have chosen to be involved. In particular, a relational model would take note of the possibility of coercion through private power, economic and otherwise. Such attention may disclose that surrogate mothers fall into different categories and that different issues concerning autonomy are raised with respect to these categories. As a result, one system of regulation might be inappropriate for all of the different categories of surrogates. ${ }^{31}$ For example, if it should turn out that nongenetically related gestational mothers are disproportionately drawn from among women of color and poorer women, that fact would raise issues concerning the limited opportunities of such women and the coercion implicit in large sums of money offered for gestational services. A relational model would also examine the institutional structures within which such transactions take place and consider the possibility of regulating the doctors, lawyers, and clinics so as to restrain those practices most likely to undermine the autonomy of the parents. These rules might be substantive rather than simply procedural. For example, the law might prohibit profitmaking from the transaction. Or, the legislature might require certain terms in the contract about who will have custody of the child in the event one of the participants changes his or her mind. The analysis of relational autonomy might also suggest that certain types of social support systems could facilitate the autonomy of the people involved in such transactions. Obviously, none of these issues can be resolved with respect to autonomy alone; their final resolution requires consideration of other values, such as the best interests of the child that will result from the procedure. My limited point here is that the autonomy part of this analysis should not end with thinking about whether or not a state actor controls the decision. The relational model of autonomy directs our attention to the social relationships and social resources that make autonomous decisions possible, rather than merely to the presence or absence of state regulation.

31. See generally Lori Andrews, Between Strangers: Surrogate Mothers, Expectant Fathers, and Brave New Babies (1989) (providing an interesting view of the different experiences of different groups of surrogate mothers). 
In sum, while I agree with Cinzia that a mixed system of government regulation and private decisionmaking will generally be the best approach, I believe the focus on public versus private ordering, that she correctly identifies as central to the present debate, is fundamentally misguided. The real issue concerns the role of individual autonomy in the values that should guide government policy in this area and, as feminist theory has demonstrated, individual autonomy is not equivalent to private ordering. A better approach would start by asking about autonomy directly, rather than about public versus private. And, in assessing autonomy, this approach should adopt a relational model of autonomy, which better captures the complex and context-dependent relationship between power (public and private) and individual autonomy. 